\title{
Early Carboniferous trilobite remains from limestones of the Dębnik Anticline, southern Poland
}

\author{
Marta Bąk $k^{1}$ Paweł Dulemba ${ }^{2}$, Krzysztof Bąk $k^{2}$ \\ ${ }^{1}$ AGH University of Science and Technology, Faculty of Geology, Geophysics and Environmental Protection, \\ Department of Geology and Geotourism; al. Mickiewicza 30, 30-059 Krakow, Poland; e-mail: martabak@agh.edu.pl \\ ${ }^{2}$ Pedagogical University of Cracow, Institute of Geography, Department of Geology; \\ ul.Podchorażych 2,30-084 Krakow,Poland; e-mail:pdulemba@up.krakow.pl,kbak@up.krakow.pl
}

(C) 2014 Authors. This is an open access publication, which can be used, distributed and reproduced in any medium according to the Creative Commons CC-BY 4.0 License requiring that the original work has been properly cited.

Received: 28 November 2013; accepted: 11 February 2014

\begin{abstract}
The presence of proetid trilobites' remnants is reported for the first time from the Lower Carboniferous limestones of the Dębnik Anticline outcropping in the Racławka Valley, situated in the eastern part of the Upper Silesian Block (southern part of the Cracow Upland). Disintegrated exoskeletons of trilobites are observed in thin sections of fine-grained, peloidal wackstones and packstones. These rocks contain also foraminifers which indicate an early Tournaisian age for this locality.
\end{abstract}

Keywords: trilobite, arthropods, Lower Carboniferous, Dębnik Anticline, Racławka Valley, Poland

\section{INTRODUCTION}

Trilobites are a highly diverse group of extinct arthropods. This group has persisted in the Earth marine ecosystems for nearly 300 million years. Over 15,000 species have been described from this group (Fortey \& Owens 1997). A trilobite body consists of three main characteristic segments (cephalon, thorax, and pygidium), divided longitudinally into three parallel lobes. The exoskeletal cuticles contain considerable amounts of calcite, which make trilobite well preserved. Despite a simple body plan, the exoskeleton morphology was very diverse.

The proetids were the only trilobite order, which auspiciously survived the Late Devonian biodiversity crisis. They first appeared in the Ordovician and terminated at the end of the Permian. During their long evolution, they survived also the end-Ordovician mass extinction and even underwent a moderate diversity in the Carboniferous times (Brezinski 1999).

We report here the recent discovery of the trilobite remnants in the Lower Carboniferous limestone of the Upper Silesian Block, a south-eastern part of the West European Platform (Fig. 1). This is a first report of trilobite remains discovered in this region. So far, well-described Carboniferous trilobites in the Polish part of the West European Platform came from the Holy Cross Mountains (Osmólska 1962, 1968, 1973).

\section{GEOLOGICAL SETTING}

Lower Carboniferous deposits, containing microfossils outcrop in the Dębnik Anticline, which belongs to the Dębnik-Siewierz fold belt (Żelaźniewicz et al. 2011), formerly named the Upper Silesian fold belt (Buła \& Habryń eds 2008, Buła et al. 2008), which creates the eastern 
part of the Upper Silesian Block (Buła et al. 2008) (Fig. 1B). This fold belt occurs between Tarnowskie Góry, Siewierz and Krzeszowice towns and contains Carboniferous-Devonian folded sediments, that were earlier included to the Variscides (Bukowy 1961), the Silesian-Cracow Anticlinorium (Bukowy 1972) or to the Silesian-Cracow fold belt (Kotas 1985, 1995). This unit is built of synclines and anticlines, including the Dębnik Anticline, of different amplitudes, which are cut by numerous faults.

The studied sediments belong to the Upper Devonian-Lower Carboniferous succession that creates the Dębnik Anticline (e.g., Klimek \& Koszarski 1955, Gromczakiewicz-Łomnicka 1974, Narkiewicz \& Racki 1984, Bełka 1985, Wolniewicz 2009). They were deposited within the carbonate platform in the Moravian-Silesian Basin (Bełka 1987). The total thickness of the Lower Carboniferous strata exceeds 1,200 m (Paszkowski
1995). These sediments came from various environments that included a deep-water intra-shelf basin, an open shelf platform and ramp, shallow water environments with lagoons, intertidal parts of the basin floor, and sabkha (Łaptaś 1982, Paszkowski 1995).

The Dębnik Anticline contains Middle Devonian (Givetian) through Lower Carboniferous (Visean) strata, dominated by limestones and dolomites (Fig. 1D). Paszkowski (1995) proposed the lithostratigraphic division of the Fammenian-Visean in this area. The Dębnik Anticline is cut by several small karst valleys, where Devonian-Carboniferous sediments are well outcropped (Fig. 1C).

The Visean limestones that create a continuous series crops out in the Czatkowice quarry and on the left side of the Racławka Valley, between Paczółtowice and the Dubie villages, located ca. $15 \mathrm{~km}$ north-west of Krakow (Fig. 1D).
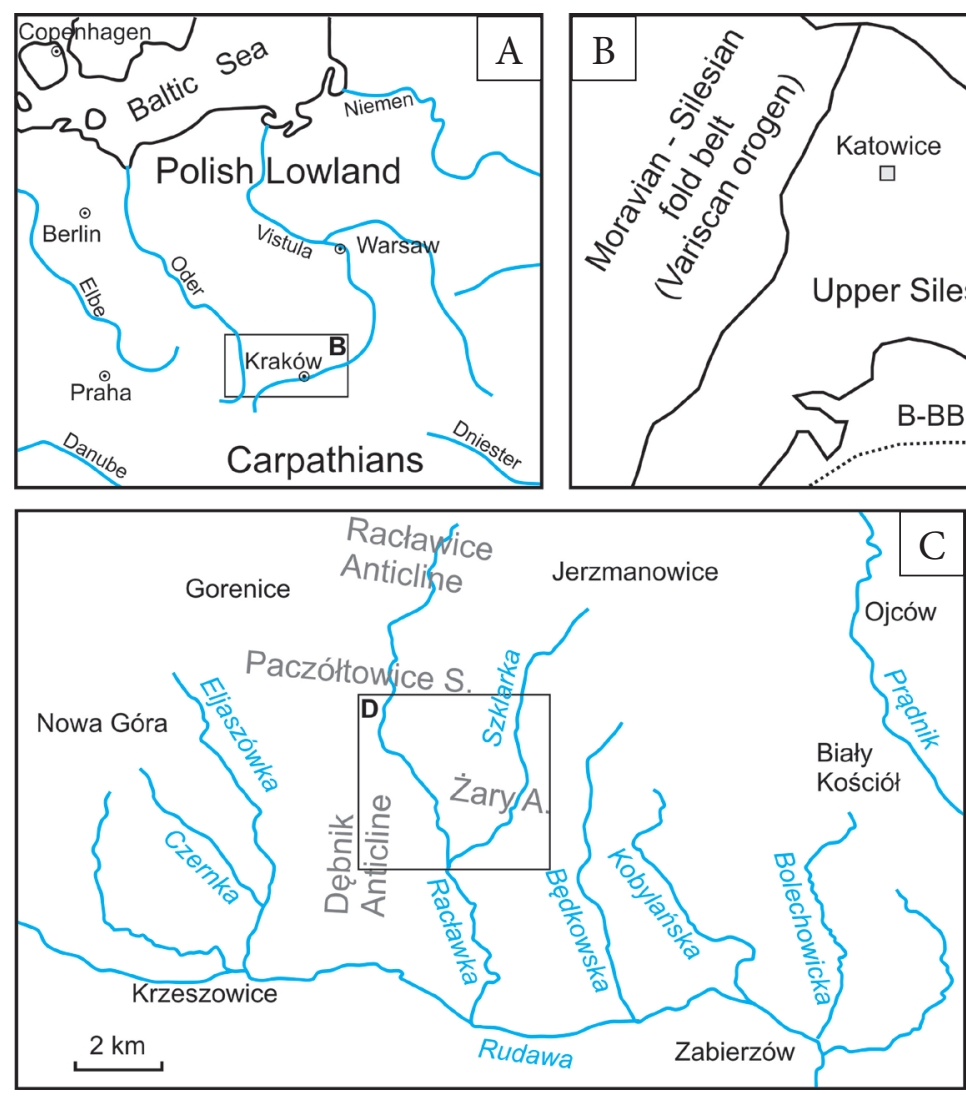

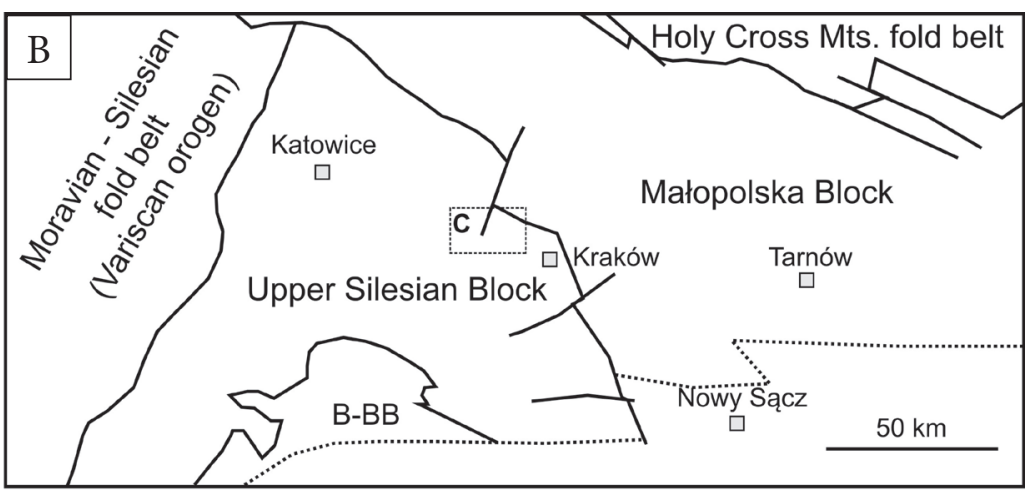

Fig. 1. Location of the study area: A) with geographic position in the Central Europe; B) on the tectonic map of the southern part of the Poland (map without Permian-Mesozoic sediments; after Żelaźniewicz et al. 2011; simplified); C) with geographic location of the Racławka Valley and its surroundings (within the Dębnik-Siewierz fold belt; after Bogacz 1980); $D$ ) in the Racławka Valley (the studied section is a thick black line with arrow; Lower Carboniferous sediments after Bogacz 1980) 


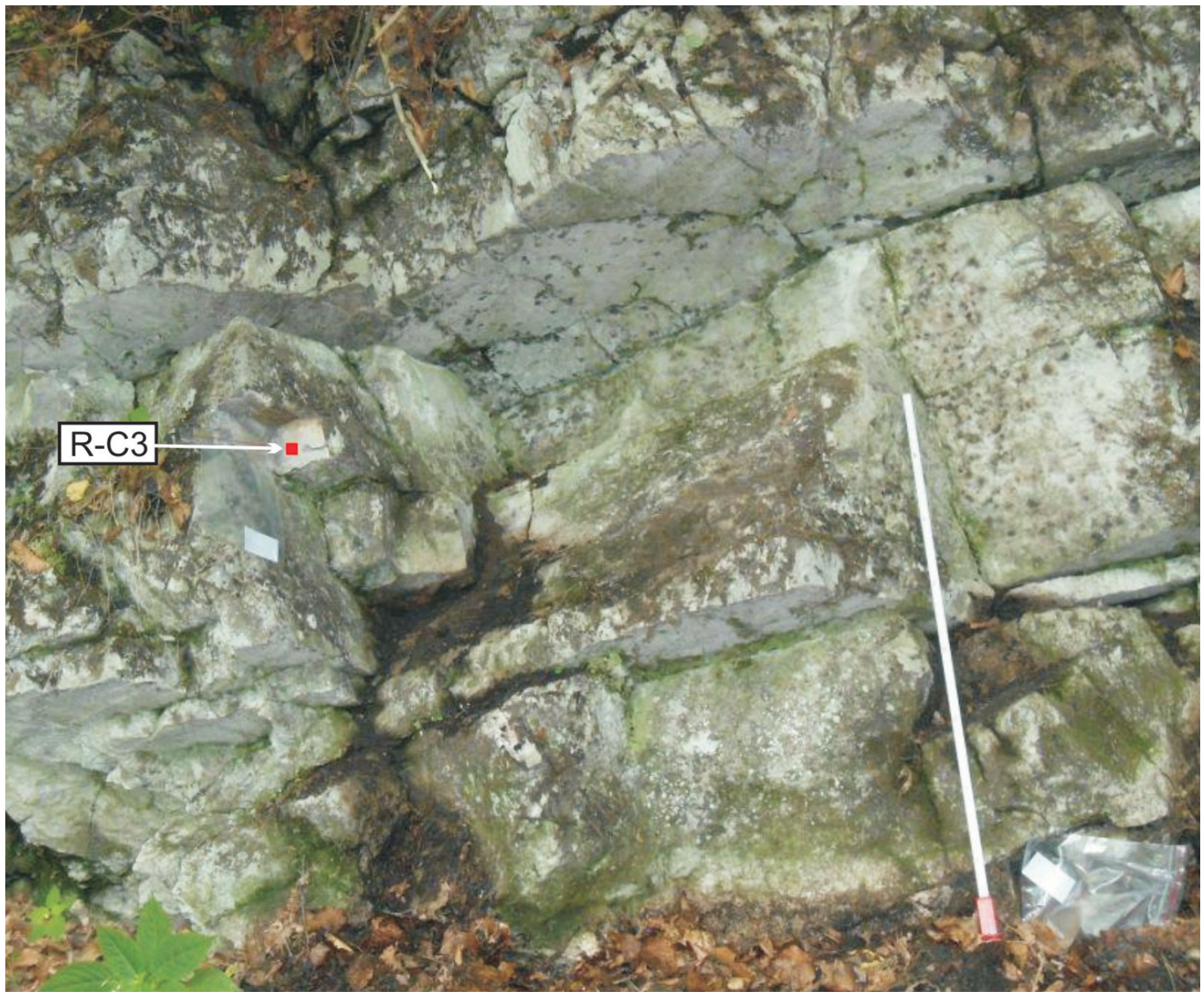

Fig. 2. Lower Carboniferous (lower Tournaisian) limestones in the Racławka Valley (Dębnik Anticline, Upper Silesian Block). The red dot marks the layer with crushed trilobite exoskeletons
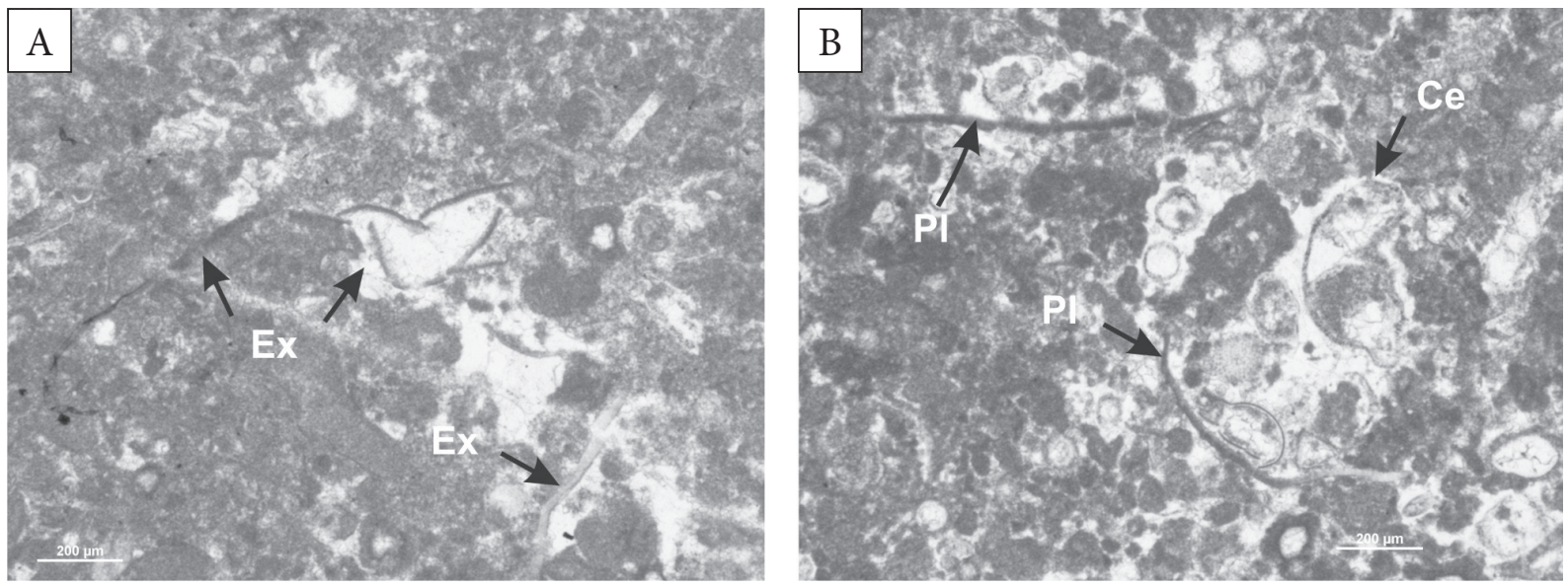

Fig. 3. Microphotographs showing microfacies of Lower Tournaisian limestone from Racławka Valley: A) peloidal wackstone with intragranular autigenic mineralization; Ex - cross-section of trilobite exoskeleton, crushed and dislocated; exoskeletal remnants are partly incorporated or/and surrounded by fecal pellets; B) packstone with abundant bioclasts which are calcispheres, foraminifers and ostracodes; trilobite fragments ( $\mathrm{Pl}$ - pleural lobe, Ce - cross-section of cephalon elements) are randomly distributed 


\section{Lithology}

The deposits investigated belong to the Dinantian Rudawa Group, as proposed by Paszkowski (1995) in the lithostratigraphic scheme for this region. Using a more detailed subdivision, these deposits represent the Szklary Formation according to definition given by Poty et al. (2007) in the stratotype, located at the Czatkowice quarry.

Samples used in this study came from grey, massive limestone, strongly cemented, forming strata from several up to $20 \mathrm{~cm}$ thick (Fig. 2). The studied succession shows low textural variation. It consists mainly of fine-grained, peloidal, skeletal wacke- and packstone (Figs 3, 4). Intragranular authigenic mineralization is visible in thin sections of the rock. Bioclasts are common (up to $40 \%$ ), however, superficially are not well visible. Bioclasts contain numerous calcispheres, moderately diverse foraminifer assemblages and ostracods (Fig. 3B). Fragments of trilobites are rare.

\section{SAMPLING AND METHODS}

Eleven samples for micropalaeontological studies were collected from natural outcrops along the touristic path in the Racławka Valley (Fig. 1D). Because of many small faults cutting the Lower Carboniferous rocks in this locality, a continuous section is composed of a few successive, separate limestone complexes, 2-4 m thick (Fig. 2). Samples were taken every $40 \mathrm{~cm}$. Oriented cross-sections were made from each of the rock sample. Microfauna and trilobite elements were found in one sample. It was analyzed and photographed using alight microscope for petrographic purposes (Nikon Eclipse 600) in the Department of Geology and Geotourism of the AGH UST and NIKON SMZ 1500 Microscope at the Pedagogical University of Cracow.

\section{RESULTS AND DISCUSSION}

\section{Biostratigraphy}

The age of these deposits has been stated as the early Tournaisian, based on the presence of foraminiferal assemblages, which belong to the earlandid and chernyshinellid groups. Based on the age-diagnostic forms such as Earlandia elegans (Rauser-Chernousova \& Reitlinger) and Eochernyshinella crassitheca (Lipina), these limestones are correlated with the Chernyshinella disputabilis Foraminiferal Zone of the South Ural (Kulagina 2013), which corresponds to the Siphonodella belkai Conodont Zone in the same region. The Szklary Formation in the Dębnik Anticline has been earlier correlated by Poty et al. (2007) with the MFZ2 Foraminiferal Zone of the Belgium Dinant's sedimentation area. Both foraminiferal zones are in the same stratigraphic position.

\section{Fragments of trilobite exoskeletons}

Trilobite exoskeletal fragments are distributed randomly in an area of $2 \times 4$ square centimeters. They can be observed in thin-sections oriented perpendicular to the rock bedding (Figs 3,4). Only some of the skeletal elements are identifiable. The trilobite remnants are mixed, and may belong to several specimens. Some of them appear to be crushed by predators. They are mixed with surrounding material by bioturbation. Other parts of the exoskeletons are incorporated into fecal pellets (Figs 3, 4).

The trilobite remnants represent both dorsal and ventral parts of the skeletons. Pleural bands from thoracic and pygidial parts prevail (Figs 3A, $\mathrm{B}, 4 \mathrm{~A}-\mathrm{C})$. Other recognizable parts are cephalon elements (Figs 3A, 4F), the axial ring (Fig. 4C), and some small spine elements of the prosopon (Fig. 4D).

The dimension of the longest pleural band is $7 \mathrm{~mm}$. The larger axial ring diameter is $2.5 \mathrm{~mm}$. These data allow estimating the maximum possible width of a complete specimen to be $1.7 \mathrm{~cm}$.

Skeletal elements possess one or two layers that form the trilobite cuticle (see pleural cross-section on Figure 4). The thicker layer, located in the inner part of the exoskeleton represents the endocuticle. It is built of calcite crystals, usually granular, with the c-axis randomly oriented or parallel to other crystals, and perpendicular to the shell surface. This layer usually contains thin seams, semi-parallel to each other, and perpendicular to the exoskeleton. Seams consist of a brown organic component. They have become dense in the uppermost part of the layer. In cross-sections which cut the skeleton parallel to its surface, the seams are visible as small holes or depressions (pits) of various sizes (Fig. 4E). Such structures are interpreted 
by some authors as canals that served for oxygen exchange or filter feeding (e.g., Dalingwater 1973, Fortey \& Owens 1999). The second outer layer of trilobite cuticle represents the exocuticle. It is about 10 times thinner, and it is mostly organic.
All skeleton elements are built of one or both of the above-mentioned layers, which possess similar thickness. One exception is a singular spine attached to a small fragment of the exoskeleton, is formed of a singular calcite crystal, or it was recrystallized.
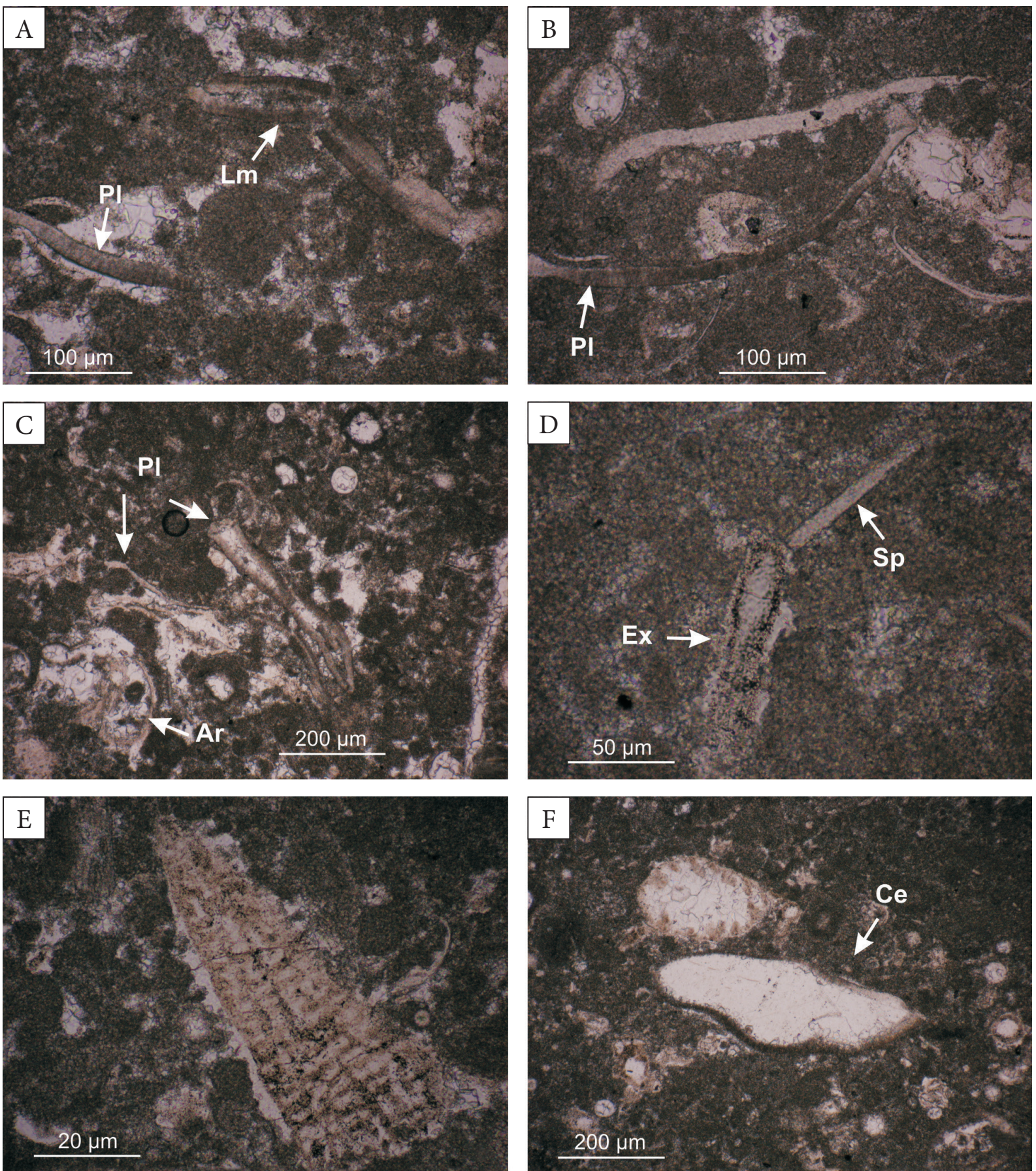

Fig. 4. Microphotographs showing wackstones and packstones with elements of trilobite skeletons in lower Tournaisian limestone from Racławka Valley: A) cross-section of pleural lobes (Pl); B) dislocated pleural bands; C) cross-section of pleural lobes (Pl) and axial ring (Ar); D) close up view of a small spine (Sp) protruding from a fragment of exoskeleton (Ex); E) part of the exoskeleton cut in parallel plane; bright parts represent calcified exoskeleton; darker places represent small holes or depression, infilled by residue of the organic layer of exocuticule; F) cross-section of an element of cephalon $(\mathrm{Ce})$ 


\section{CONCLUSIONS}

The discovered trilobite remnants in the Racławka Valley were derived from the fine-grained, peloidal packstone of the Szklary Formation, and deposited on the carbonate platform of the Moravian-Silesian Basin. These deposits contain biogenic components previously recognized as foraminifers, calcispheres and ostracodes, but also disintegrated exoskeletons of trilobites. Although no complete skeleton has been found, the presented discovery enriches our knowledge concerning the distribution of Carboniferous trilobites in the ancient Moravian-Silesian Basin. The stratigraphic position of limestones containing the discovered trilobite remnants is documented as lower Tournaisian based on foraminiferal assemblages.

This paper was supported by AGH grant no. 11.11.140.173 to M. Bak and by Pedagogical University of Cracow grant no. UP-WGB-3 to K. Bak.

\section{REFERENCES}

Bełka Z., 1985. Lower Carboniferous conodont biostratigraphy in the north eastern part of the Moravia-Silesia Basin. Acta Geologica Polonica, 35, 1-2, 33-60.

Bełka Z., 1987. The development and decline of the Dinantian carbonate platform: an example from the MoraviaSilesia Basin. [in:] Adams A.E., Miller J. \& Wright V.P. (eds), European Dinantian Environments, John Wiley \& Sons, Chichester, 177-188.

Bogacz K., 1980. Budowa geologiczna paleozoiku dębnickiego. Rocznik Polskiego Towarzystwa Geologicznego, 50, 183-208.

Brezinski D.K., 1999. The rise and fall of late Paleozoic trilobites of the United States. Journal of Paleontology, 73, 164-175.

Bukowy S., 1961. Sprawa poszukiwań ropy naftowej w Hercynidach. Kwartalnik Geologiczny, 5, 1, 57-61.

Bukowy S., 1972. Budowa podłoża karbonu Górnośląskiego Zagłębia Węglowego. Prace Instytutu Geologicznego, 61, 23-50.

Buła Z. \& Habryn R. (eds), 2008. Geological-structural Atlas of the Palaeozoic basement of the Outer Carpathians and Carpathian Foredeep [in Polish and English]. Państwowy Instytut Geologiczny, Warszawa.

Buła Z., Żaba J. \& Habryn R., 2008. Regionalizacja tektoniczna Polski - Polska południowa (blok górnośląski i blok małopolski). Przegląd Geologiczny, 56, 10, 912-920.

Dalingwater J.E., 1973. Trilobite cuticle microstructure and composition. Palaeontology, 16, 4, 827-839, pls. 107-109.

Fortey R.A. \& Owens R.M., 1997. Evolutionary History. [in:] Kaesler R.L. (ed.), Treatise on Invertebrate Paleontology. Part O: Arthropoda 1, Trilobita. Volume 1: Introduction, Order Agnostida, Order Redlichiida. The Geological
Society of America \& The University of Kansas. Boulder Colorado \& Lawrence, Kansas, 249-287.

Fortey R.A. \& Owens R.M., 1999. The Trilobite Exoskeleton. [in:] Functional Morphology of the Invertebrate Skeleton. John Wiley \& Sons, 537-562.

Gromczakiewicz-Łomnicka A., 1974. Upper Visean conodont fauna from the Carboniferous limestone north of Krzeszowice (environs of Cracow, Poland). Rocznik Polskiego Towarzystwa Geologicznego, 44, 4, 475-480.

Klimek S. \& Koszarski L., 1955. Stratygrafia Dębnika w porównaniu $\mathrm{z}$ dewonem obszarów sąsiednich. Przegląd Geologiczny, 3, 8, 388.

Kotas A., 1985. Structural evolution of the Upper Silesian Coal Basin (Poland). Compte Rendu. 10 $0^{\text {th }}$ International Congress on Carboniferous Stratigraphy and Geology, Madrid 1983, 3, 459-469.

Kotas A., 1995. Lithostratigraphy and sedimentologic paleogeographic development. Moravia, Silesian, Cracovian region, Upper Silesian Coal Basin. [in:] Zdanowski A. \& Żakowa H. (eds), The Carboniferous System in Poland, Prace Państwowego Instytutu Geologicznego, $148,124-134$.

Kulagina E.I., 2013. Taxonomic diversity of foraminifers of the Devonian-Carboniferous boundary interval in the South Urals. Bulletin of Geosciences, Czech Geological Survey, Prague, 88, 2, 265-282.

Łaptaś A., 1982. Sedymentacja utworow węglanowych dewonu środkowego rejonu Dębnika. Studia Geologica Polonica, 75, 59-100.

Narkiewicz M. \& Racki G., 1984. Stratygrafia dewonu antykliny Dębnika. Kwartalnik Geologiczny, 28, 513-546.

Osmólska H. 1962. Fammenian and Lower Carboniferous Cyrtosymbolinae (Trilobita) from the Holly Cross Mountains, Poland. Acta Paleontologica Polonica, 7, 53-222.

Osmólska H. 1968. Contribution to the Lower Carboniferous Cyrtosymbolinae (Trilobita). Acta Paleontologica Polonica, 13, 1, 119-150.

Osmólska H. 1973. Tournaisian trilobites from Dalnia in the Holly Cross Mts. Acta Paleontologica Polonica, 23, $1,61-81$.

Paszkowski M. 1995. Krakow region. [in:] Dvorak J. (ed.), Evolution of the Polish-Moravian Carbonate Platform in the late Devonian and early Carboniferous: Holy Cross Mts., Krakow Upland, Moravian Karst. $13^{\text {th }}$ International Congress on Carboniferous-Permian, Kraków, Poland. Guide to Excursion B4, Państwowy Instytut Geologiczny, Warszawa, 1-35.

Poty E., Berkowski B., Chevalier E. \& Hance L., 2007. Sequence stratigraphic and biostratigraphic correlations between the Dinantian deposits of Belgium and Southern Poland (Krakow area). Proceedings of the $15^{\text {th }}$ International Congress on the Carboniferous-Permian, Utrecht, 2003, Royal Netherlands Academy of Arts and Sciences, 97-107.

Wolniewicz P., 2009. Late Famennian stromatoporoids from Dębnik Anticline, southern Poland. Acta Palaeontologica Polonica, 54, 2, 337-350.

Żelaźniewicz A., Aleksandrowski P., Buła Z., Karnkowski P.H., Konon A., Oszczypko N., Ślączka A., Żaba J. \& Żytko K., 2011. Regionalizacja tektoniczna Polski. Komitet Nauk Geologicznych PAN, Wrocław. 